\title{
Introduction: Thinking About Seeds
}

\author{
Michel Pimbert
}

Abstract Seed diversity is crucial to the sustainability of food and agricultural systems. Yet as Michel Pimbert's survey of the global 'state of seeds' reveals, both wild and domesticated varieties are disappearing under an onslaught of human-driven pressures. Planetary crises-the sixth great extinction and climate change-constitute one. Industrialized agriculture is another: just three crops (maize, rice and wheat) currently supply over $60 \%$ of the calories humanity obtains from food. The impacts of this impoverishment on small and Indigenous farmers, ecosystems, food security and human health are manifold, and understanding them demands that we unravel a range of intermeshed social and political factors. Disparities in wealth, gender and ethnicity, for instance, determine the way seeds are cultivated, conserved, collected and exchanged. And the primary domains of seed governance-state, corporate and farm-wield different, often unequal powers. By confronting these complexities, Pimbert asserts, we can map ways of managing seeds equitably, to support human and planetary wellbeing.

M. Pimbert $(\bowtie)$

Centre for Agroecology, Water and Resilience, Coventry University, Coventry, UK e-mail: michel.pimbert@coventry.ac.uk

Y. Nishikawa and M. Pimbert (eds.), Seeds for Diversity and Inclusion, https://doi.org/10.1007/978-3-030-89405-4_1 
Keywords Biodiversity loss - Indigenous peoples · Farmers · Adaptive management of diversity $\cdot$ Seed governance

Sustainable food and agriculture depend on the continued availability and quality of, and access to, seeds of cultivated and wild plants for renewal and adaptation to dynamic change. Different types of seed biodiversity ('cultivated', 'reared' or 'wild') are used by different people at different times and in different places, and so contribute to ecological sustainability, food security and livelihood strategies in a complex manner. Understanding how cultivation, management, collection, use and marketing of different types of domesticated and wild seeds are affected by differences in wealth, gender, race, ethnicity and age is essential for making equitable decisions on how to conserve, exchange and use seeds for human and planetary well-being.

And diversity in the seeds of cultivated and wild plants is indeed key in this context. Domesticated, semi-wild and wild seed plants are closely associated in most food- and fibre-growing environments. For example, rural and urban home gardens are typically structurally complex, and provide many multifunctional benefits to surrounding ecosystems and to people. Evidence shows that high levels of inter- and intra-specific diversity in cultivated and wild seed plants - especially locally adapted landraces and wild crop relatives - are preserved in home gardens throughout the world (Galluzzi et al., 2010).

The interactions between the environment, seeds and local management practices also influence evolutionary processes such as introgression from wild relatives, hybridization between cultivars, mutations and natural and human selections. This generates a diversity of seeds (landraces and wild ecotypes) that are well adapted to the mosaic of changing local environmental conditions and community preferences. 
As one component of agricultural biodiversity (see Box 1.1), seed diversity is thus vitally important for the design of sustainable agroecosystems and just food systems ${ }^{1}$ (FAO, 1998; Mulvany, 2020; Peschard \& Randeria, 2020; Pimbert, 1999).

\section{Box 1.1: Agricultural biodiversity}

Agricultural biodiversity (or agrobiodiversity) refers to the variety and variability of animals, plants and micro-organisms key to food and agriculture, and which result from the interaction between the environment, genetic resources and human management systems and practices. The term takes into account not only genetic, species and agroecosystem diversity and the different ways in which land and water resources are used for production, but also cultural diversity, which influences human interactions at all levels. It has spatial, temporal and scale dimensions. It comprises the diversity of genetic resources (varieties and breeds, for example) and species used directly or indirectly for food and agriculture (including, in the definition offered by the Food and Agriculture Organization of the United Nations (FAO), crops, livestock, forestry and fisheries) for the production of food, fodder, fibre, fuel and pharmaceuticals. It also covers the diversity of species that support production (such as soil biota, pollinators and predators) and those in the wider environment that support agroecosystems (agricultural, pastoral, forest and aquatic), as well as the diversity of the agroecosystems themselves.

Source FAO (1998)

This book focuses on the governance and management of cultivated and wild seeds in diverse contexts. Drawing on case studies from Japan, Taiwan, Bhutan, Myanmar, Iran, Italy, Peru and Scotland, this collection of papers offers a nuanced view on practices that exist alongside a continuum of informal to formal processes-from local to global. The main message of this book is that seed governance and management need to be transformed and based on principles of decentralization, dynamic adaptation and cultural and spiritual diversity, as well as democracy and inclusion.

${ }^{1}$ A food system gathers all the elements (environment, people, inputs, processes, infrastructures and institutions, for example) and activities that relate to the production, processing, distribution, preparation and consumption of food, and the outputs of these activities, including socioeconomic and environmental outcomes (HLPE, 2014). 


\subsection{Diverse Seeds Under Threat}

Over the last 60 years, numerous scientific reports have documented the rapid loss of biodiversity important for food and agriculture (FAO, 2019; IPBES, 2019). The Food and Agriculture Organization of the United Nations (FAO) reported:

Soil, water, and genetic resources constitute the foundation upon which agriculture and world food security are based. Of these, the least understood and most undervalued are plant genetic resources. They are also the resources most dependent upon our care and safeguarding. And they are perbaps the most threatened. (FAO, 1996)

Most notably, the global expansion of genetically uniform monocultures of industrial farming has accelerated the erosion of seed diversity. According to $\mathrm{FAO}, 75 \%$ of plant genetic diversity has been lost, as farmers worldwide abandon their locally adapted crop varieties for the genetically uniform, high-yielding varieties promoted by industrial and Green Revolution-influenced agriculture (FAO, 2004).

While regularly updated, this expert knowledge on the extent of genetic erosion in seeds is nevertheless incomplete. First, much of this academic and policy literature on food and agriculture focuses mainly on seeds of a few domesticated plants out of the handful of commercially valuable commodity crops in world trade. ${ }^{2}$ Far less research and development and policy attention has been given to the seeds of the many locally and nationally important food crops in different regions of Africa, Asia, the Americas, Polynesia and Europe (FAO, 2010; Prescott Allen \& Prescott Allen, 2018). This institutional bias is even more striking in light of the fact that out of the 250,000 identified and described plant species, some 30,000 are edible and around 7000 have been cultivated or collected for food at one time or another (Harlan, 1995).

The true extent and impact of the loss of cultivated and wild plant seeds on myriad peasant and Indigenous communities are unnoted by

2 Only 6 crops - wheat, soybeans, maize, rice, barley and rapeseed-cover $50 \%$ of arable land, and only 9 crops account for $66 \%$ of total crop production (FAO, 2019). About 100 species contribute $90 \%$ of all calories in the human diet (Hufford et al., 2019) and three (rice, wheat and maize) represent about $60 \%$ of calories and $56 \%$ of proteins from plants consumed globally, while using nearly $50 \%$ of irrigation water. 
many development professionals, scientists and inter-governmental organizations. Outsiders' expert knowledge often fails to grasp the complex, diverse and risk-prone local realities of indigenous and peasant communities (Chambers, 1997, 2017). Simply put, the seed diversity that matters to so many Indigenous and peasant farmers as well as to small- and medium-scale producers is not a priority for national and international ${ }^{3}$ agricultural research and development.

\subsection{The Unprecedented Challenges Caused by Seed Extinctions}

The loss of seed diversity on farmlands and the commons is a feature of the sixth mass extinction of biodiversity the world is currently experiencing (IPBES, 2021). This irreversible loss of inter- and intra-specific crop seed diversity has created several existential threats and major challenges, as follows.

\subsubsection{Growing Malnutrition and Food Insecurity}

Just 30 crops supply $95 \%$ of the calories we obtain from food, while only 4 crops-maize, rice, wheat and potatoes-supply over $60 \%$. Although the diversity of processed foods available in supermarkets and local shops seems remarkable, it is all, in truth, based on a handful of staple crops. The food industry endlessly re-engineers and recombines these into a huge array of these products. Ingredients such as high-fructose corn syrup, palm oil, refined flour, sugar and soy appear repeatedly in the ultraprocessed foods that give the illusion of dietary diversity in the global food system (HLPE, 2017).

This unprecedented and ongoing reduction in dietary richness is having a significant impact on human health worldwide. For example, the decline in seed and dietary diversity is linked to a drop in human gut microbiota, the community of micro-organisms living in the gastrointestinal tract. Many of the common pathologies of the twentyfirst century-inflammatory bowel disease, type 2 diabetes and obesity, for example-are associated with a reduction in microbiotic richness

3 The Consultative Group for International Agricultural Research (CGIAR) and its 15 international centres have a mandate to work on a relatively small number of commodity crops: https://www.cgiar.org/research/research-centers/. 
(Heiman \& Greenway, 2016). By contrast, healthy individuals with resilient auto-immune systems have highly diverse gut microbiota.

Food and farming practices based on a significant diversity of wild and cultivated seed plants can increase dietary diversity and thereby improve human health by encouraging species-rich gastrointestinal microbiomes. The devastating impacts of COVID-19 and the enduring pandemic have also underscored the importance of diverse nutritious diets to strengthen peoples' immune system (Naja \& Hamadeh, 2020; Yeoh et al., 2021). More generally, equitable access to, and use of, a diversity of seeds of cultivated and wild plants is also a key condition for food and nutrition security in rural and urban contexts (Pimbert \& Lemke, 2018).

\subsubsection{Unsustainable Food and Agricultural Systems}

The International Assessment for Knowledge and Agricultural Science for Development (IAASTD $+10,2020$ ) and other scientific studies (HLPE, 2019; IPCC, 2019) highlight the urgent need to shift from industrial uniformity to biodiversity-rich farming in the face of increasingly rapid climate change, market volatility and potential near-future pandemics. Industrial food and farming are more than ever unsustainable because all relevant biophysical indicators are turning negative, fast, steeply, dangerously; the emerging context is beyond human experience; and the costs of mitigation, adaptation and remediation are rising sharply.

Industrial agriculture's lack of resilience to shocks and stresses is striking. The uniform monocultures of industrial farming and that based on benefits of the Green Revolution are particularly susceptible to global warming and associated changes in rainfall patterns, hurricane frequency and incidence of pest attacks. The Intergovernmental Panel on Climate Change (IPCC) points to the need to substantially increase crop genetic diversity to enable adaptation to climate change in the coming decades (IPCC, 2019, 2022).

Indeed, adaptation to climate change and recovery from climateinduced disasters hinges on the availability and free access to a diversity of seeds needed to rediversify farming systems for socioecological resilience (Chapter 8). In this regard, agroecology offers viable avenues for mitigation of and adaptation to climate impacts (FAO, 2018; HLPE, 2019). Rooted in endogenous development visions (see Box 1.2), agroecology seeks to diversify agroecosystems by combining many different crop varieties and species into functional wholes that operate like ecosystems, 
reducing insect pest and diseases, recycle nutrients, conserve soils and water and adapt to climate change (Altieri, 1995; Gliessman, 2015). East Asian agroecologists are now re-discovering the endogenous farmer practices that sustained food and agriculture for centuries in countries like Japan, Korea and China (King, 1911). However, state spending for research and development (R\&D) continues to massively support industrial agriculture, a high emitter of greenhouse gases. ${ }^{4}$ Worldwide, there is a chronic lack of investment in research for biodiversity-conserving agroecology, both domestically and through overseas aid. ${ }^{5}$

\section{Box 1.2: Endogenous development theory}

In 1980s Japan, the sociologist Kazuko Tsurumi was among those developing a comprehensive theory of endogenous development, or 'development from within', as an alternative to ideas of modernization originating in Europe and the United States.

The basic goal of endogenous development as Tsurumi envisaged it is for all humans and communities to meet needs in food, clothing, shelter and medical care, as well as to create conditions in which individuals can fully achieve their potential. But the paths to that goal follow diverse processes of social change. Individuals and groups in each region must autonomously create social visions and ways forward to the goal by adapting to their own ecological systems, and by basing development programmes on their own cultural heritage and traditions.

Source Tsurumi, K. Aspects of Endogenous Development in Modern Japan Research Papers, Series A-36. Institute of International Relations, Sophia University, Tokyo, 1979

4 The global food system is responsible for at least $37 \%$ of total net anthropogenic greenhouse-gas emissions (IPCC, 2019).

5 In the United States, for example, a recent analysis of funding by the US Department of Agriculture (USDA) showed that projects with an emphasis on agroecology represented only $0.6-1.5 \%$ of the entire 2014 USDA Research, Extension, and Economics budget (Delonge et al., 2016). UK development aid barely supports agroecology: overseas aid for agroecological projects in Africa, Asia and Latin America accounts for less than $5 \%$ of agricultural aid and less than $0.5 \%$ of the total UK aid budget since 2010 (Pimbert \& Moeller, 2018). Similarly, EU funding to FAO and other Rome-based UN agencies and the Green Climate Fund neglects agroecological R\&D (Moeller, 2020); the lion's share of funding goes to industrial agriculture, which is responsible for most greenhouse gas emissions. 


\subsubsection{Loss of Ecosystem Functions, Goods and Services}

From pollination to natural pest control and water purification, ecosystems provide key functions, goods and services, and they too depend on promoting inter- and intra-specific seed diversity on farms and surrounding landscapes (IPBES, 2019). Diverse seed-producing wild and cultivated plants are centrally involved in the mediation of multiple ecological functions and processes, at different scales (Pimbert, 1999). Valuable ecological processes that result from the interactions between species, and between species and the environment, include biogeochemical cycling, the maintenance of soil fertility and water quality, providing food and refuges for pollinators, and regulating climate. The erosion of seed diversity - and the ensuing loss or reduction in the abundance of cultivated and wild plants in space and time-fundamentally undermines vitally important ecological functions and processes that sustain and renew the material basis of social and economic life (IPBES, 2019).

Appropriate responses to these unprecedented existential threats require a radical transformation in the governance of seeds, and the systems in which they are embedded.

\subsection{The Politics of Seed Governance}

Decisions on how, why, where and by whom cultivated and wild plant seeds are conserved, exchanged and used are critical for the future of food and agriculture as well as the well-being of people and planet.

Seed governance is defined here as the set of political, social, economic and administrative rules, processes and systems that determine the way decisions by the various actors are taken and implemented for the management and use of seeds. Governance also includes the rules and processes through which decision-makers are held accountable locally, nationally and internationally.

Complex local livelihoods and food provisioning depend on cultivated, semi-wild and wild plants in most rural and peri-urban communities across the world (Guijit et al., 1995). Governance therefore needs to be comprehensive and inclusive in its focus on seeds of both cultivated and wild plants important for food and agriculture. 


\subsubsection{Domesticated/Cultivated Seed Plants}

Governance centres here on the conservation of crop seeds (in situ and ex situ), seed multiplication, seed hygiene, seed certification and catalogues, plant breeding, distribution and exchange of seeds, Indigenous and peasant knowledge, informal seed exchange networks, collective and customary rights, plant breeders' rights and private property rights, commercialization of seeds and seed corporations (see Chapters 4, 5, 6, 9, 10 and 12). The most contested issues in national seed laws and policies are on peasants' and farmers' rights to save, use, sow, re-sow, exchange, share and sell farm produce, including seeds of varieties protected by plant breeders' rights.

\subsubsection{Semi-Wild/Wild Seeded Plants}

Governance encompasses the management of lands where wild crop relatives and wild food plants live, including the commons (such as grasslands, forests, wetlands and drylands) where wild plants live, reproduce and scatter their seeds. These are mostly human-managed ecosystems and landscapes with long history of coevolution between people and nature. Many indigenous, pastoral and peasant communities obtain diverse foods and fibres from these anthropogenic landscapes (Gómez-Pompa \& Kaus, 1992; Pimbert \& Borrini, 2020) and biocultural heritage territories (see Chapter 4). Policies that restrict local access to these humanized landscapes are often contested by Indigenous and peasant communities who have historically depended on them for their livelihoods and culture (FPP, 2020; Ghimire \& Pimbert, 1997).

\subsection{The Actors and Institutions Governing Seeds}

There are multiple actors with contrasting powers involved in making decisions on the governance of seeds. They can be described in terms of Marc Nerfin's typology of the Prince, the Merchant and the Citizen (Nerfin, 1986). 


\subsubsection{The Prince: The State}

Different levels of government-from national to local as well as intergovernmental international institutions - are different manifestations of the state, or as Nerfin has it, 'the Prince'. Nation states, although by no means all of them, have signed up to several international treaties and declarations key to the governance of seeds (see Box 1.3). Under these treaties and commitments, states have obligations to ensure the consistency of their national laws and policies, and of international agreements and standards to which they are party regarding the right to seeds. Here is an example from Article 19 of the United Nations Declaration on the Rights of Peasants (UNDROP):

States shall ensure that seed policies, plant variety protection and other intellectual property laws, certification schemes and seed marketing laws respect and take into account the rights, needs and realities of peasants and other people working in rural areas. ${ }^{6}$

However, the implementation of joined-up and consistent approaches at national and local levels is problematic for most governments. Siloed administrations, top-down interventions, structural constraints and sectoral approaches often hamper coordinated and relevant action on the ground. For example, the governance and management of cultivated and wild seeds are generally the responsibility of separate ministries, reflecting an enduring opposition between development and conservation. In turn, this often leads to a mismatch between standard conservation and development approaches and the multitude of diverse local realities and needs of communities dependent on both cultivated and wild diversity (Chambers, 1997; Ghimire \& Pimbert, 1997; Scott, 2020).

6 The legally binding International Treaty on Plant Genetic Resources for Food and Agriculture (ITPGRFA) states that contracting parties should, as appropriate, and subject to its national legislation, take measures to protect and promote farmers' rights, including: protection of traditional knowledge relevant to plant genetic resources for food and Agriculture; the right to equitably participate in sharing benefits arising from the utilization of plant genetic resources for food and agriculture; and the right to participate in making decisions, at the national level, on matters related to the conservation and sustainable use of plant genetic resources for food and agriculture. 
Box 1.3: The major institutions of seed governance

The Convention on Biological Diversity (CBD). Adopted in 1992, the CBD protects important elements of peasants' right to seeds, including through provisions to ensure the protection of Indigenous and local communities' traditional knowledge, and the fair and equitable sharing of the benefits arising out of the utilization of genetic resources ${ }^{7}$

The International Treaty on Plant Genetic Resources for Food and Agriculture (ITPGRFA). This is the most important international treaty for the recognition and protection of farmers' and peasants' right to seeds. Its preamble states that 'the rights recognized in this Treaty to save, use, exchange and sell farm-saved seed and other propagating material, and to participate in decision-making regarding, and in fair and equitable sharing of the benefits arising from, the use of plant genetic resources for food and agriculture, are fundamental to the realization of Farmers' Rights, as well as to the promotion of Farmers' Rights at national and international levels'. The responsibility for realizing farmers' rights rests with national government, as stated in the treaty. ${ }^{8}$

The United Nations Declaration on the Rights of Indigenous Peoples (UNDRIP). This declaration recognizes Indigenous peoples' right to maintain, control, protect and develop their own seeds and their ownership of those seeds. 9

The Agreement on Trade-Related Aspects of Intellectual Property Rights (TRIPS). Adopted by the World Trade Organization (WTO). Member States of the WTO must protect intellectual property rights over plant varieties either by patents, an effective sui generis system (a system of its own kind) or a combination of both. Patents are the most comprehensive form of protection that can be granted because they give the right-holders-in many cases corporations-exclusive rights over plant-related inventions. ${ }^{10}$

\footnotetext{
7 https://www.cbd.int/convention/.

8 http://www.fao.org/3/i0510e/i0510e.pdf.

9 https://www.un.org/development/desa/indigenouspeoples/declaration-on-the-rig hts-of-indigenous-peoples.html.

10 https://www.wto.org/english/docs_e/legal_e/27-trips_03_e.htm.
} 
International Union for the Protection of New Varieties of Plants (UPOV) and its Convention (UPOV Convention). The UPOV Convention protects the rights of plant breeders who have developed varieties that are new, distinct, uniform and stable (DUS). UPOV requires peasants to obtain authorization to sell protected seeds. This practically prohibits the realization of farmers' rights. Moreover, the UPOV 1991 Act further prohibits farmers from saving, reusing, and exchanging these seeds (except in a very limited way on their own farms). ${ }^{11}$

The Voluntary Guidelines on the Responsible Governance of Tenure of Land, Fisheries, and Forests in the context of National Food Security (VGGT). Agreed by the UN Committee on World Food Security, it promotes responsible governance of land, forests and fisheries under all forms of tenure: public, private, communal, indigenous, customary and informal. ${ }^{12}$

The United Nations Declaration on the Rights of Peasants and Other People Working in Rural Areas (UNDROP). This is the most recent UN instrument that recognizes new human rights-including the right to seeds, land, natural resources and food sovereignty via agroecology, local seeds, local markets, gender equity and participatory decision-making. 13

\subsubsection{The Merchant: Seed Corporations}

Over the last 60 years, the commercial seed sector has become increasingly consolidated and concentrated. Many small and family-owned seed companies have been absorbed into larger seed firms through mergers and acquisitions. The most recent mergers reduced the number of major seed companies to four: Bayer-Monsanto, DowDuPont/Corteva, ChemChina-Syngenta and BASF. This handful of corporations control more than $60 \%$ of global proprietary seed sales (Howard, 2020). Agriculture in industrialized countries sources most of its seeds from them. In other regions of the world, the proportion of commercial seeds used

\footnotetext{
11 https://www.upov.int/portal/index.html.en.

12 http://www.fao.org/tenure/voluntary-guidelines/en/.

13 https://www.geneva-academy.ch/joomlatools-files/docmanfiles/UN\%20Declara tion $\% 20$ on $\% 20$ the $\% 20$ rights $\% 20$ of $\% 20$ peasants.pdf.
} 
is still relatively low-approximately $30 \%$ in India, and less than $10 \%$ in Africa.

Unlike many family seed companies and cooperatives (Chapter 10), transnational seed corporations strongly promote a controllable uniformity through proprietary technologies such as hybrid seeds that meet DUS $^{7}$ criteria, patented genetically modified (GM) seeds and gene drive technologies, and more generally through discourse, policy influence and private-public R\&D partnerships that further their political and economic interests (Clapp \& Fuchs, 2009).

As the so-called Fourth Industrial Revolution (4IR) for agriculture gains momentum (WEF, 2018), global seed corporations focus on rolling out 4IR technologies ${ }^{8}$ designed to transform food and agriculture. To this end, they are building partnerships with other agro-industrial giants in a range of arenas, from artificial intelligence, robotics, digital sequencing, synthetic biology, big data, pesticides, farm machinery, e-commerce, investment finance and private equity. In the meantime, their use of pro-business investor dispute panels allows seed corporations to block government interventions to regulate their activities, as well as to seek financial compensation for lost market opportunities and investments. In effect, investor-state dispute settlement (ISDS) is a system through which investors can sue countries for alleged discriminatory practices. ${ }^{9}$

In this unprecedented thrust to further enclose the commons, corporate seed governance promotes ever-increasing uniformity, privatization, financialization, control, centralization and coercion (Aubry, 2019; FIAN, 2020; Hache \& Spash, 2021; IPES Food \& ETC, 2021).

7 Under the International Union for the Protection of New Varieties of Plants (UPOV) rules, a new plant variety must comply with the requirements of distinctness, uniformity and stability (DUS) in order to be registered and protected.

8 The Fourth Industrial Revolution (4IR) for food and agriculture is based on a package of 12 technologies, including precision agriculture to 'optimize the use of agricultural inputs and water', gene editing, big data and advanced analytics, the 'Internet of Things' for real-time traceability of the food chain, alternative proteins, and nutrigenetics for personalized nutrition (WEF, 2018).

${ }^{9}$ For examples and more information see http://isds.bilaterals.org/the-basics\#. 


\subsubsection{The Citizen: Food Producers and Consumers}

There are more than 570 million farms worldwide, most of which are small and family farms (Lowder et al., 2016). Of these, $74 \%$ are located in Asia, with China alone representing $35 \%$ and India $24 \%$ of all farms. Some $72 \%$ of the world's farms are smaller than 1 hectare (ha) in size; $12 \%$ are 1 to 2 ha in size (small farms); and $10 \%$ are between 2 and 5 ha. Only $6 \%$ of the world's farms are larger than 5 ha. Family farmers work $75 \%$ of the world's agricultural land and are responsible for most of the world's food and agricultural production (Lowder et al., 2016).

As historical custodians of the land, small farmers have co-created, with nature, myriad locally adapted seeds. In Southeast Asia, for instance, the high diversity of ethnic groups within a relatively small region has produced extraordinary diversity in Indigenous vegetables, as different groups favour specific culinary and agronomic properties (Gill et al., 2013). Farm-saved seed and informal seed exchanges are common practices among small and family farmers, with informal seed systems providing 60 to $100 \%$ of seeds planted by Indigenous and peasant communities in the Global South (Almekinders \& Louwaars, 2002). These small-scale producers conserve, share, and use diverse seeds through their decentralized governance and adaptive practices (Brac de la Perrière, 2014; IPC, 2017; Peschard \& Randeria, 2020).

The US farmer, environmental activist and poet Wendell Berry has said that 'eating is an agricultural act' (Berry, 1990). Every human thus plays a direct and indirect role in enabling (or undermining) seed diversity in agri-food systems. People's decisions to source food locally generally help to conserve and enhance seed diversity in short food chains and local food systems-for example, in Scotland (Chapter 9) and other parts of Europe (Kneafsey et al., 2013). By contrast, people's ability to support seed diversity is much more limited when they rely on long-distance value chains based on uniformity and economies of scale. This is because food choices-and which seeds are ultimately conserved and used-are largely determined by distant corporations that control the different links of these global value chains, from seeds and farm inputs to industrial food processing and supermarkets (HLPE, 2017).

Nerfin's third system, the Citizen, emphasizes autonomy and the need for citizens to self-organize and self-govern in local settings. ${ }^{10}$

\footnotetext{
10 https://www.daghammarskjold.se/publication/another-development-third-system/.
} 
Throughout the world, many Indigenous and peasant communities still develop their own place-specific seed governance and management rules. Mutual agreements on the roles, rights and obligations of different local actors allow them to adaptively govern and manage their seed commons (Chapters 2, 4, and 12; Borrini-Feyerabend et al., 2007).

The Citizen can also exert power from below to change actions taken by the Prince or the Merchant (Chapter 12). The collective agency and power of citizens partly depends on their capacity to educate, mobilize for autonomous action through horizontal networks and organize to change policies and institutions to reflect their own priorities and cosmovisions. This implies radical changes in power relations and people's self-determination in the governance and management of seeds, as advocated by movements for endogenous development (Chapters 3 and 13; Kato, 2020) and food sovereignty (Chapter 2).

By considering various international examples and local intitiatives, this book highlights the collective capacity of a growing international movement to reclaim seeds for diversity and autonomy in food and farming.

\section{REFERENCES}

Almekinders, C. J. M., \& Louwaars, N. P. (2002). The importance of the farmers' seed systems in a functional national seed sector. Journal of New Seeds, 4(1-2), 15-33. https://doi.org/10.1300/J153v04n01_02

Altieri, M. A. (1995). Agroecology: The science of sustainable agriculture. Boulder, Colorado: Westview Press.

Aubry, S. (2019). The future of digital sequence information for plant genetic resources for food and agriculture. Frontiers in Plant Science, 10(1046). https://doi.org/10.3389/fpls.2019.01046

Berry, W. (1990). The pleasures of eating. In W. Berry, What are people for? North Point Press.

Borrini-Feyerabend, G., Pimbert, M. P., Farvar, M. T., Kothari, A., \& Renard, Y. (2007). Sharing power: A global guide to collaborative management of natural resources (2nd ed.). Earthscan, IIED and IUCN.

Brac de la Perrière, R. A. (2014). Semences paysannes, plantes de demain [Peasants' seeds, plants of tomorrow]. Charles Léopold Mayer.

Chambers, R. (1997). Whose reality counts? Putting the last first. Intermediate Technology Development Group.

Chambers, R. (2017). Can we know better? Reflections for development. Practical Action Publishing. 
Clapp, J., \& Fuchs, D. (2009). Corporate power in global agrifood governance. MIT Press.

DeLonge, M. S., Miles, A., \& Carlisle, L. (2016). Investing in the transition to sustainable agriculture. Environmental Science \& Policy, 55(1), 266-273. https://doi.org/10.1016/j.envsci.2015.09.013

FAO. (1996). The state of the world's plant genetic resources for food and agriculture. Rome, FAO.

FAO. (2004). Erosion of plant genetic diversity. FAO News. Retrieved December 28, 2021, from https://www.fao.org/Newsroom/en/focus/2004/51102/ article_51107en.html

FAO. (1998). International Technical Workshop organized jointly by the Food and Agriculture Organization of the United Nations and the Secretariat of the Convention on Biological Diversity (SCBD), with the support of the Government of the Netherlands 2-4 December 1998. www.fao.org/sd/epdirect/EPre0063. htm

FAO. (2010). The second report on the state of the world's plant genetic resources for food and agriculture. FAO.

FAO. (2019). The state of the world's biodiversity for food and agriculture, J. Bélanger \& D. Pilling (Eds.). FAO Commission on Genetic Resources for Food and Agriculture Assessments. FAO.

FIAN. (2020). Rogue capitalism and the financialization of territories and nature. P. Seufert, R. Herre, S. Monsalve \& S. Guttal (Eds.). FIAN International, Transnational Institute and Focus on the Global South.

FPP. (2020). Human rights in the post-2020 Global Biodiversity Framework: options for integrating a human-rights based approach to achieve the objectives of the Convention on Biological Diversity. Forest Peoples Programme. Retrieved July 1, 2021, from https://www.forestpeoples.org/sites/default/ files/documents/humanrights\%20Eng_0.pdf

Galluzzi, G., Eyzaguirre, P., \& Negri, V. (2010). Home gardens: Neglected hotspots of agro-biodiversity and cultural diversity. Biodiversity Conservation, 19, 3635-3654. https://doi.org/10.1007/s10531-010-9919-5

Ghimire, K. B., \& Pimbert, M. P. (1997). Social change and conservation: Environmental politics and impacts of national parks and protected areas. Earthscan/Routledge.

Gliessman, S. R. (2015). Agroecology: The ecology of sustainable food systems. Boca Raton, Florida: CRC Press.

Gill, T. B., Bates, R., Bicksler, A., Burnette, R., Ricciardi, V., \& Yoder, L. (2013). Strengthening informal seed systems to enhance food security in Southeast Asia. Journal of Agriculture, Food Systems, and Community Development, 3(3), 139-153. https://doi.org/10.5304/jafscd.2013.033.005

Gómez-Pompa, A., \& Kaus, A. (1992). Taming the wilderness myth: Environmental policy and education are currently based on Western beliefs about 
nature rather than on reality. BioScience, 42(4), 271-279. https://doi.org/ $10.2307 / 1311675$

Guijit, I., Hinchcliffe, F., Melnek, M., Bishop, J., Eaton, D., Pimbert, M. P., Pretty, J., \& Scoones, I. (1995). The hidden harvest: The value of wild resources in agricultural systems. IIED.

Hache, F., \& Spash, C. L. (2021). Nature, life \& relations-'Optimised': A policy brief on the Dasgupta Review. Green Finance Observatory. Retrieved July 19, 2021, from https://greenfinanceobservatory.org/2021/05/26/the-das gupta-review-deconstructed/

Harlan, J. R. (1995). The living fields: Our agricultural heritage. Cambridge University Press.

Heiman, M. L., \& Greenway, F. L. (2016). A healthy gastrointestinal microbiome is dependent on dietary diversity. Molecular Metabolism, 5, 317-320. https://doi.org/10.1016/j.molmet.2016.02.005

HLPE. (2014). Food losses and waste in the context of sustainable food systems. A report by the High Level Panel of Experts on Food Security and Nutrition of the Committee on World Food Security, Rome.

HLPE. (2019). Agroecological and other innovative approaches for sustainable agriculture and food systems that enhance food security and nutrition. A report by the High Level Panel of Experts on Food Security and Nutrition of the Committee on World Food Security, Rome.

HLPE. (2017). Nutrition and food systems: A report by the High Level Panel of Experts on Food Security and Nutrition of the Committee on World Food Security. CFS.

Howard, P. H. (2020). How corporations control our seeds. In S. Jarayaman \& K. De Master (Eds.), Bite back: People taking on corporate food and winning. University of California Press.

Hufford, M. B., Mier, B., Teran, J. C., \& Gepts, P. (2019). Crop biodiversity: An unfinished magnum opus of nature. Annual Review of Plant Biology, 70, 727-751. https://doi.org/10.1146/annurev-arplant-042817-040240

IAASTD +10 . (2020). Transforming our food systems. In H. R. Herren \& B. Haerlin (Eds.), The IAASTD +10 advisory group. Zurich: Biovision.

IPBES. (2019). Summary for policymakers of the global assessment report on biodiversity and ecosystem services of the Intergovernmental Science-Policy Platform on Biodiversity and Ecosystem Services. IPBES.

IPBES. (2021). Nature's dangerous decline 'unprecedented'; Species extinction rates 'accelerating'. Media Release. IPBES. Retrieved July 1, 2021, from https://ipbes.net/news/Media-Release-Global-Assessment

IPC. (2017). Peasants give life to biodiversity. IPC. Retrieved July 3, 2021, from http://www.foodsovereignty.org/wp-content/uploads/2016/ 10/ENGLISH_spreads_lowRes_.pdf 
IPCC. (2019). Climate change and land. Special Report: Summary for Policymakers. IPCC. Retrieved July 19, 2021, from https://www.ipcc.ch/srccl/

IPCC. (2022). Climate change 2022: Impacts, adaptation, and vulnerability. New York: Working Group II contribution to the Sixth Assessment Report of the intergovernmental panel on climate change.

IPES Food \& ETC. (2021). A long food movement: transforming food systems by 2045. IPES Food.

Kato, M. (2020). Minakata Kumagusu: The first Japanese environmentalist. Educational Philosophy and Theory. https://doi.org/10.1080/00131857. 2020.1770612

King, F. H. (1911). Farmers of forty centuries: Permanent agriculture in China, Korea, and Japan. Rodale Press.

Kneafsey, M., Venn, L., Schmutz, U., Balázs, B., Trenchard, L., Eyden-Wood, T., et al. (2013). Short food supply chains and local food systems in the EU: $A$ state of play of their socio-economic characteristics. Publications Office of the European Union.

Lowder, S. K., Skoet, J., \& Raney, T. (2016). The number, size, and distribution of farms, smallholder farms, and family farms worldwide. World Development, $87,16-29$.

Moeller, N. I. (2020). Analysis of funding flows to agroecology: The case of European Union monetary flows to the United Nations' Rome-based agencies and the case of the Green Climate Fund. CIDSE \& CAWR.

Mulvany, P. (2020). Sustaining agricultural biodiversity and heterogeneous seeds. In A. Kassam \& L. Kassam (Eds.), Rethinking food and agriculture. Woodhead Publishing.

Naja, F., \& Hamadeh, R. (2020). Nutrition amid the COVID-19 pandemic: A multi-level framework for action. European Journal of Clinical Nutrition, 74, 1117-1121.

Nerfin, M. (1986). Neither prince nor merchant: Citizen, an introduction to the third system. In S. J. Patel (Ed.), World economy in transition (pp. 47-59). Pergamon Press.

Peschard, K., \& Randeria, S. (2020). 'Keeping seeds in our hands': The rise of seed activism. The Journal of Peasant Studies, 47(4), 613-647. https://doi. org/10.1080/03066150.2020.1753705

Prescott Allan, R., \& Prescott Allen, C. (2018). Genes from the wild: Using wild genetic resources for food and raw materials. London: Routledge (originally published in 1988).

Pimbert, M. P. (1999). Sustaining the multiple functions of agricultural biodiversity. IIED Gatekeeper Series, 88. IIED.

Pimbert, M. P., \& Lemke, S. (2018). Using agroecology to enhance dietary diversity. UNSCN News, 43, 33-42. 
Pimbert, M. P., \& Moeller, N. I. (2018). Absent agroecology aid: On UK agricultural development assistance since 2010. Sustainability, 10, 505. https:// doi.org/10.3390/sul0020505

Scott, J. C. (2020). Seeing like a state: How certain schemes to improve the human condition have failed. Yale Univerity Press.

WEF. (2018). Innovation with a purpose: The role of technology innovation in accelerating food systems transformation. Geneva: World Economic Forum.

Yeoh, Y. K., Zuo, T., Lui, G. C.-Y., et al. (2021). Gut microbiota composition reflects disease severity and dysfunctional immune responses in patients with COVID-19. Gut, 70, 698-706.

Open Access This chapter is licensed under the terms of the Creative Commons Attribution 4.0 International License (http://creativecommons.org/licenses/ by $/ 4.0 /$ ), which permits use, sharing, adaptation, distribution and reproduction in any medium or format, as long as you give appropriate credit to the original author(s) and the source, provide a link to the Creative Commons license and indicate if changes were made.

The images or other third party material in this chapter are included in the chapter's Creative Commons license, unless indicated otherwise in a credit line to the material. If material is not included in the chapter's Creative Commons license and your intended use is not permitted by statutory regulation or exceeds the permitted use, you will need to obtain permission directly from the copyright holder.

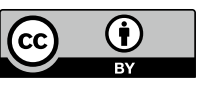

